\title{
The analysis of internal policy implementation on the behaviour of government officer
}

\author{
Lisdawati Muda ${ }^{*}$ \\ Prodi MPI IAIN Sultan Amai Gorontalo, Indonesia
}

\begin{tabular}{l} 
Article Info \\
\hline Article history: \\
Received Aug $04^{\text {th }}, 2021$ \\
Revised Sept $16^{\text {th }}, 2021$ \\
Accepted Oct $29^{\text {th }}, 2021$ \\
\hline
\end{tabular}

\section{Keyword:}

Internal Policy

Work Performance

Civil Servant Officer (ASN)

\begin{abstract}
This article aims to analyse the implementation of internal policy on Civil Servant Officer work performance at IAIN Sultan Amai Gorontalo. Internal policy is an urgent item in leading an institution because it guarrantes the individual work performance. The workers will get their good work performance since the internal policy lies on worker side. The method of this research was qualitative descriptive by using field observation and interview as data collection. The data were analyzed into three steps, namely data reduction, data display, and data conclusion. The participants of this research were five administration staff, three lecturers, and five students. It used purposive sampling. The result showed that the implementation of internal policy at IAIN Sultan Amai Gorontalo was not effective. It caused by three problems. Firstly, it is lack of evaluation during the internal policy implemented and after it was implemented. Secondly, it is lack of coordination among stakeholders and the workers (administration staff, lecturers, and the students). Thirdly, it is lack of collaboration among stakeholder and staffs.
\end{abstract}

(C) 2021 The Authors. Published by IICET.

This is an open access article under the CC BY-NC-SA license (https://creativecommons.org/licenses/by-nc-sa/4.0)

\section{Corresponding Author:}

Lisdawati Muda,

Prodi MPI IAIN Sultan Amai Gorontalo, Indonesia

Email: lisdawati02muda75@gmail.com

\section{Introduction}

Campus is one of institution which running three work performances. It is known as "tridharma perguruan tinggi". There are three activities on them, namely running teaching and learning process, doing research and publication, and implementing community service. Campus has a management system which focuses on educational system. The top manager of campus is a rector who has staffs included lecturers, students, and administration staffs. Lecturers and administration staffs required by the system of government requirement, thus they are called civil servant officer. They have to work according to the regulation have been determined by government law. Therefore, civil servant officers are regulated through the government laws and government rules. However, the rector as the top manager in campus is available to make and apply internal policy. It is to extend the government laws and rules. The internal policy is made to improve the work performance of civil servant officers.

Sari, et. all (2014) in her research "Analyze School Internal Policy System in Managing Fix Assets found that internal policy is important to be implemented because its prevent all aspects of institution, such as human resource and asset. As Syifa Nurrillah (2014) confirmed that internal policy implementation is important because it has two main goals which referred to accounting internal policy and administrative internal policy. 
She researched about the effect of human resource competence, the implementation of Regional monetary system, the utilization of Information technology, and internal policy system toward work report quality.

Work performance as one of this variable of this research deals with the ASN (Civil Servant Officer) competence and behavior in doing their task and function. ASN work performance has been researched many times, such as Patri Juari (2018), who studied about the work achievement of ASN at BKD (the Center of ASN officer and Human Resources Development) Bulungan Regency North Kalimantan. Muhammad Aji Ibrahim, et.all (2019) studied the factors were affected to ASN work achievement at Bontang City. Gugun Geusan Akbar (2010) studied about the correlation between ASN income intensive system with the ASN work achievement and work motivation. James Haryando Simatupang, et.al (2018) studied the role of ASN work discipline toward the effectivity of public service at Sorong City. Yosy Arisandy (2017) studied about performance Appraisal by using the combination between key performance indicator method and 360 degree feedback. Astri Anjarwati \& Sitti Aminah (2014) studied about the evaluation of policy implementation of government at Yogyakarta city toward inclusion education.

These articles above showed that some factors, such as discipline, work motivation, income sytem influenced to the quality of ASN work performance. Other aspect is work performance seems as a special case, where every place has its own problems. Thus, analyzing work performance in IAIN Sultan Amai

Gorontalo is one case because since this article written, nothing article has discussed the ASN work performance at IAIN Sultan Amai Gorontalo. However this research was analyzed the implementation of internal policy on ASN work performance, both lecturers and administration staffs. Therefore, it answered the question about how was the implementation of internal policy on ASN work performance at IAIN Sultan Amai Gorontalo.

\section{Method}

This study uses a type of qualitative research where the purpose of qualitative research is to capture the deepest meaning of an event, symptom, fact of occurrence, reality, or a particular problem and not to study or prove the existence of a causal relationship or correlation of the existence of a problem or event. The use of qualitative methods in this study is to obtain a realistic-holistic description of the behavior of the Government apparatus (ASN) and social interaction between ASN at IAIN Sultan Amai Gorontalo. The case study was used to determine the participants' perceptions of the behavior of ASN at IAIN Sultan Amai Gorontalo in carrying out their duties.

The data collection technique in this research is the collection of secondary data and primary data. The primary data in this study were obtained from the results of in-depth interviews and observations. While secondary data is data obtained indirectly from the field. Secondary data in this study is data from IAIN Sultan Amai Gorontalo. Research informants in research are subjects who understand information about the object of research as actors. The informants in this study were government officials (ASN) at IAIN Sultan Amai Gorontalo. Data analysis is the process of organizing and sorting data into patterns, categories, and basic units of description so that themes can be found and working hypotheses can be formulated as suggested by the data. The data obtained through interviews and observations were then carried out in data processing with the following stages: analyzing data, reducing data, compiling in units or smoothing data recording, and interpreting data. In qualitative research, so that a study is said to be valid, accurate, and reliable, triangulation is used. Triangulation is seeing a reality from various aspects so that it is more credible and accurate.

\section{Results and Discussions}

Based on the result of the research, the behaviour of ASN at IAIN Sultan Amai Gorontalo showed as follows:

\section{Making group between Friend}

Basically, humans are social beings who have dependence between each other. However, in some organizations, including those within IAIN Sultan Amai Gorontalo, human nature as a social being is sometimes misused. The results showed that there was a group of close friends who motivated each other and helped each other if one of his friends had problems with other people, even though his friends made mistakes, they would get support from their group friends as long as they were still in line with their wishes. The prominent behavior of government officer in this context is to make friends with other colleagues, if they both do not have a position or opportunity for a job that is considered profitable. However, the friendship in the peer group was left by ASN individuals who felt dissatisfied because some of their group friends were given positions, even more so that ASN people who were uncomfortable with the success of their group friends 
turned to attack and twist facts in order to get sympathy and recognition of their performance. from other people.

In addition to the group behavior above, the behavior of other ASN people is to form a group of friends who always carry on their stuff, cooperate if there are activities on or off campus. In fact, there are often some people from this group of friends who like to cheer other people outside of their group just to strengthen ties with their group.

Uniquely, from the group of friends that were formed, there were unscrupulous members of the same group of friends who gossiped about their other friends when they weren't together. This kind of phenomenon seems to illustrate that a group of peer friends formed is intended to help ease work, but it cannot be ignored, also that friendship groups often become a medium for mutual support, slandering is not only aimed at other people who are not included in the group but also Groupmates who seem to get along with each other sometimes harbor mutilating behaviors.

From the results of observations and interviews, it was found that the behavior of individuals who like to vilify their fellow group of friends or other friends who are not in a group is usually based on jealousy, unwillingness to compete and the behavior of wanting to monopolize work. There is nothing wrong with ASN forming groups. to give each other, exchange ideas and so forth. However, friendship groups that are formed and are mostly used as a forum for negative behavior as previously described, are feared to be group behavior that is difficult to understand, as conveyed by one of the informants who stated that the behavior carried out by ASN officials confirmed that in the IAIN Sultan Amai Gorontalo it would be very difficult to know who is a friend and who is actually an opponent. The behavior of mutually defaming each other is feared of becoming a time bomb for the perpetrators and a loss of credibility for ASN who experience slander and fake news.

\section{Less Friendly and The Most Corrected}

From the results of interviews with informants and observations of researchers, it was found that among ASNs there are people who usually feel the most correct in their work. This kind of behavior model occurs in some work units. If there are work matters that involve unscrupulous lecturers and administrative staff, sometimes it creates conflicts between the two.

Related to this behavior, it is clear that the jealousy of administrative staff towards the duties and authority of lecturers, such as lecturers who have finished teaching must be informed by structural officials if the lecturer leaves the campus due to personal matters or needs. To remember and understand administratively the main duties of an ASN (lecturer) is carrying out the duties and functions of the Tridharma of Higher Education services to students or students in this case the teaching and learning process, but if a lecturer is given the mandate by the top leadership of the institution to occupy a structural position, then the position is an additional task so that there is no requirement of rules which is binding if a lecturer has carried out teaching activities to students reporting to structural officials.

Ironically, the additional tasks given by the leadership of structural officers are so thick with subjective behavior that influences lecturers to get structural administrative services for personnel or is commonly known and understood in a part of modern organizational theory, namely Human Resources Development (HRD). The services referred to, such as the management of promotion, there is almost never prior notification if there is a lecturer whose time has met the requirements to take care of promotion, notification of periodic salary decree changes, study assignments / study permits and other administrative file management are usually fully left to the lecturer concerned.

Facts in the field show that some lecturers complain and feel that their rights are neglected to get information about the management of various kinds of files for the benefit of their profession. The principle is that ASNs who have structural position responsibilities either as lecturers or are appointed as ASN administrative personnel, especially in the HRD section are obliged for them to carry out their duties to the maximum maybe in accordance with the provisions of the laws and regulations regarding the rights of lecturers and other personnel administration. It is not the opposite to allow lecturers to work and strive for their own career and professional interests.

In line with the lack of service behavior felt by some lecturers towards the behavior of ASN individuals as has been stated, the less friendly behavior in providing services was also felt by some students. Difficulties in contacting lecturers in mentoring and lecture affairs still often occur, as well as difficulties in administering administration related to administrative matters for students who often get less friendly service from civil servants.

Thus the structural leadership and administrative staff are partners in supporting the teaching profession to carry out the teaching process to students and provide other academic services as well as community service, 
so that our common goal of improving the quality of Tridharma Perguruan Tinggi services will be maximally achieved.

\section{Lack of discipline at work}

Lack of discipline is a pathology in all organizations. The success and success of an organization, including higher education institutions, is highly dependent on the discipline of the ASN both lecturers and administrative staff.

The lack of discipline shown and carried out by civil servants is considered to greatly hinder the achievement of educational goals. Observations of lack of discipline were observed from several ASNs, especially those working in supporting units and institutions as well as study programs, often arriving late. There were also structural civil servants who came almost every day just to be absent, then left to take care of their interests, even though the apparatus' working hours started from 7.30 to 16.30 . The same is the case with lecturers who rarely teach on the grounds of carrying out research and community service, so lecture hours are postponed for several days. And the consequence of the delay in the lecture process must be compacted and replaced at a later time which results in a lack of attention and concentration of students when participating in the teaching and learning process.

In addition to the behavior of ASN lecturers who lack discipline in teaching, less disciplined behavior is shown by the presence of missing and damaged items that often occur. Usually, things that are lost have a tendency to be taken by irresponsible persons, such as televisions, fans, projectors, computers, money, bowls, plates and so on. From the results of observations and interviews, researchers found facts in the field, the occurrence of theft was due to the negligence of ASN who served as security, cleaning officers and other ASN in the work unit of the occurrence of theft such as in research and community service institutions (LP2M), laboratories, halls and classrooms.

The indiscipline of civil servants who often come late to lock the room, keep watch at the designated location, leave the guard post more, clean and tidy up the room late, hope for each other and pass work responsibilities on to others, are always used by irresponsible persons. Thieves are free to enter and exit because they feel safe and have ample opportunity to be able to take belongings from campus, or belong to ASN that are stored in the work room.

\section{Behavior of friendship}

Silaturrahmi relationship is a fabric of brotherhood, kinship or kinship relationship. Silaturrahim between fellow ASN within the IAIN Sultan Amai Gorontalo environment is known to have been well established since a long time ago. This behavior is always seen when carrying out activities carried out on campus such as National Holidays ceremonies, KORPRI apples, celebration of Islamic holidays, and others. In addition, the relationship among ASNs is seen at every celebration, wedding party, funeral ceremony and so on. Almost all civil servants try to take part in voluntary activities held both on and off campus. The atmosphere of mutual cooperation often occurs to make a celebration event a success, as evidenced by the contribution of material, energy and thoughts.

From the four behaviors that dominate in ASN within the IAIN Sultan Amai Gorontalo environment, the researcher believes that to minimize the negative behavior above, several strategies that can be applied to the organization in question are as follows: a) Improve the implementation system for the recruitment of ASN / CPNS.An article accessed at the address, http: www.zonareference.com dated 11 July 2018 on several explanations of implementation based on expert opinion, including:KBBI, Imlementation is the implementation of the application Budi Winarno, implementation is actions that must be done by someone, a group of people who have been given the responsibility to carry out something that has been determined; $b$ ) Nurdin Usman, implementation implies that it boils down to activities, actions, actions or the existence of a technical mechanism. Implementation includes activities that have been pre-programmed and not just like the implementation of activities. Implementation is a systems and engineering action; c) Masmanian and Sabatier, implementation is knowledge that is formed after the determination of directed planning and becomes the attention of the government as a policy maker. It is also stated that implementation is the attitude that is applied after the policy is made and ratified as state policy; d) From the explanation of the experts mentioned above, the researcher is of the view that implementation is a form of decision making in an organization or institution, applying a system of policies / rules that are enforced within the organization supported by the ability to create and innovate that does not conflict with state regulations and religious norms. An example is the consideration of the recruitment policy for honorary ASN and ASN CPNS in educational institutions including IAIN Sultan Amai Gorontalo; e) It needs to be appreciated by all the success of the government today regarding the formulation and implementation of government policies in the recruitment of ASNs in government organizations through the passing grade system. This system provides great benefits and benefits 
to the wider community. Collusion and nepotism practices no longer apply, because everyone has the same right and opportunity to participate in the CPNS acceptance selection through the application by answering each item of question. Amazingly, the results of the answers obtained can be seen directly by other people, so that the opportunity to cheat is not possible. . However, at the end of the selection stage, an interview test or practical exam is usually carried out in accordance with the selected formation. The test is carried out at the selected organization or institution. The examiner is usually an official or ASN within the organization concerned. For example, ASN applicants who choose a lecturer formation, then the interview test or practical exam must be taken at the chosen institution. In order to produce quality ASN, not only intellectually intelligent, but also emotionally and spiritually intelligent, government organizations, especially IAIN Sultan Amai Gorontalo, as the implementer of the ASN acceptance test need to make internal policies that can support government policies or regulations regarding the recruitment of professional ASNs. The policies that can be implemented according to researchers are:

\section{Interview tests and practical exams are designed to determine the behavior or personality of the ASN candidate.}

Although the written test contains questions to determine the attitudes of the ASN candidate, the personality test should be sharpened even more during the interview and practical tests. Sebuah artikel yang ditulis tahun 2018 menuliskan, manfaat test keperibadiansebagai berikut:

First, assessing the potential intelligence of $A S N$ candidates

The potential intelligence in question is intelligence which includes emotional intelligence, spiritual intelligence and does not only prioritize intellectual intelligence. In a higher education institution, the combination of the three realms of intelligence is an absolute concern, because in higher education institutions socializing more with other people and the wider community is closely related to teaching and learning activities and all university functions. Therefore, emotional intelligence and spiritual intelligence that support intellectual intelligence greatly determine the competence of ASN in carrying out its role.

Second, knowing the personality or behavior of the ASN candidate.

Personality tests through interviews are items that need to be carried out in order to find out the personality and behavior of ASN candidates in overcoming problems and techniques that are carried out in case of pressure and workload that must be resolved.

Third, estimating the performance performance and work ethic of ASN candidates

The interview tests and practical exams in this section make it easier for institutions to see the right ASN candidates for admission. Tenacity and patience in practicing the type of work chosen as well as dexterity in overcoming the workloads encountered can be clearly seen when undergoing the test as intended.

Fourth, the placement of ASN candidates

This test makes it easy for decision makers to place recruited ASN candidates according to their talents, interests and expertise. ASN placement according to their competence and expertise creates a comfortable and pleasant working atmosphere for ASN.

From the four benefits of personality tests for ASN candidates, researchers argue that as an institution engaged in the education sector, of course IAIN Sultan Amai Gorontalo has to seriously make and implement internal policies regarding personality tests and behavior of ASN candidates, whether lecturers or administrative staff. The ASN candidate examiner team should be assigned to people who are truly experts in their fields, such as psychologists, regardless of rank and position, seniority and other things that are considered subjective in the implementation of the test. If the interview test is given to the examiner even though he is an institution official but not an expert in psychology, he will be easily fooled by the best behavior shown by the ASN candidate at the time of the interview.

\section{Implementation of formulation and performance evaluation policies for civil servants}

For ASN with the status of CPNS, the preparation and evaluation of their performance before being appointed as Civil Servants (CPNS) should be a serious concern of the organization, in this case the leadership of the related institutions. Likewise, for honorary civil servants as well as contract workers, formulation and performance evaluation needs to be implemented seriously. So far, the performance evaluation for newly appointed ASNs has been running, but it is considered not optimal. Civil servants who have not performed their duties several times should not be recommended to become civil servants. Likewise, for honorary ASN and contract workers in the first month of work, it is still necessary to apply a drafting system that is educational and humane before submitting a decree and signing a work contract. If during the initial evaluation period and work flirting it is deemed unable to arouse enthusiasm and work responsibility, the signing of the SK and work contract needs to be canceled and the recruitment of ASN is held in accordance with the standard operating procedures applicable in the organization or institution. 


\section{Assertiveness in implementing internal policies for ASN}

In connection with the function of higher education as a forum for intellectuals as stated earlier, the researcher argues that in order to maintain the function of higher education in order to avoid things that are not educational, assertiveness in implementing policies for ASN is a must that cannot be postponed. The implementation of a strict system among all elements of higher education is considered to be very helpful in developing the best personality and character for ASN, even though in essence all civil servants who work in tertiary institutions are reliable, intelligent and professional personnel. However, it cannot be ignored that humanly there are ASNs that behave deviating from the predetermined rules. Even though the behavior that has a negative impact that often occurs in the ASN environment is a human error, the assertiveness of all components, especially elements of higher education leaders, is expected to be able to appear courageous and act decisively. It can be ascertained that if the mistakes that often occur are committed by civil servants and do not get decisive action it can develop into group behavior and even have the potential to become organizational behavior which will later breed in the IAIN Sultan Amai institution. If this happens, it will be difficult for the institution to progress and develop.

Decisive action against ASN is considered capable of minimizing behavior as stated in the previous discussion in accordance with the behavior that has been carried out and how big the impact is due to the behavior that has been done by problematic ASN persons. Firmness in giving sanctions to problematic ASN persons starts from providing advice and warnings. Higher education must be more observant in responding to the behavior of civil servants who are proven to be defamatory, they must make oral and written statements in various mass media to restore the good name of victims of slander. Policies and strict sanctions for individuals who slander, discredit others, damage credibility, destroy careers and the good name of others can be minimized by internal policies so that they do not turn into behavior that damages the image of the institution due to behavior by irresponsible individuals. In a similar vein, assertiveness to civil servants who are less disciplined in carrying out their duties needs to also get the best solution, because less disciplined behavior lacks a smile, is impolite and so on in providing services will have an impact on the low quality of educational services in tertiary institutions. If a tertiary institution implements unsatisfactory services to the community, especially services to students, it tends to be left out and has minimal interest. An ideal university has standard operating procedures that are in direct contact with the needs of institutional users, more specifically ASN lecturers, ASN officials and administrative staff, and students. In order for higher education institutions to run effectively, efficiently, the Academic Community and administrative ASNs create harmonious relationships between each other namely creating behavior that helps each other in the improvement and enhancement of performance and is responsible for providing more humane services. In relation to the behavior of helping each other in higher education, academic services are needed in accordance with government regulations and internal institutional policies. ASN for lecturers provides academic services for students, ASN for administration provides services for lecturers and students, likewise ASN for lecturers helps ASN for administration in accordance with their roles and authorities and other services among others that may be able to assist their respective assignments. Rewansyah (2011: 62) describes that internal services in an organization depend on the needs of the organization concerned in the form of vertical and horizontal services.

Internal services are performed by other staff units that do not provide services directly to customers or users outside the organization. Services that can be applied to the internal service model are informationgiving services, consideration-giving services, services on behalf of the head, supervising, representing the head (alter ego services). which will be explained later. The reason the researchers only took two services was emphasizing the role of ASNs as providers and recipients of services based on their own duties and authorities, without anyone feeling that their role was more than other ASNs.

\section{The two forms of service are as follows:}

Providing information (informative services)

Providing information among civil servants in the university environment can be a reflection of individual, group and even organizational behavior. Communication methods and strategies describe the behavior of the communicant. If the method of conveying information is carried out by ASN with a gentle, polite, and polite attitude and character, it shows that the ASN has a humble and humble personality. Likewise, if an ASN person delivers information with a wry face, high voice, chooses words and sentences that hurt the feelings of the other person, then it is certain that the person in question is behaving rudely, underestimating and being arrogant.

\section{Providing consideration (advisory service)}

His ideal in higher education organizations is the behavioral model of giving and receiving consideration to ASN, which describes their respective roles and duties. For lecturers, the most prominent behavior related to giving consideration is providing consideration services for contracting courses and the number of credits that 
can be taken by students, consideration of exam models and guidance of scientific papers. Responding to the lecturer's assignment in giving consideration to the behavior shown is modest, authoritative and has intellectual character. However, this behavior is accompanied by assertive behavior adjusted to the attitude shown by the student during consultation and asking for consideration.

In contrast to the behavior of the ASN administration in giving and requesting considerations, they should try to coordinate or relate more with their superiors as task providers and considerations and policy makers.

Policy appointed a team of experts

Policy to appoint a team of rights experts to assist ASN in trouble. Placement of time and division of tasks for experts tailored to the needs of the organization in accordance with the situations and conditions associated with ASN behavior such as a team of psychologists, IT experts, financial management experts, and others. Psychologists threaten ASN behavior that has problems, whether it's relationship problems with any work or personal problems that lead to neglect of duties. Psychologists assigned to solve problems provided by ASN have a positive impact in fostering enthusiasm, self-confidence and other positive behaviors that can motivate ASN performance improvement. Similar to the placement of a team of experts in the IT field will greatly assist ASN in completing its required tasks. mastery of IT skills. It is undeniable that the emergence of lazy behavior and lack of discipline in ASN individuals is caused by the lack of knowledge and skills about IT, an era whereas now all tasks and work completion cannot be separated from the existence of IT. Supervision and mentoring for ASN, especially in the university environment, is one of the supporting factors for the realization of the vision and mission of the organization, even though universities are places of work for great people from various disciplines. Researchers see a variety of behaviors that are detrimental and contrary to the conditions of ASN in a higher education institution as a common negligence in any organizational environment. The unpleasant behavior that occurs in ASN is also likely not intentional, but the skills they have, the many pressing problems and other causes. The matter of supervision and assistance by assisting experts is very helpful even though only reminding or listening to problematic civil servants.

Basically, to create a conducive working climate and as a form of accountability for institutional development, many strategies have been carried out by policy makers at IAIN Sultan Amai Gorontalo. These policies include making application-based programs to determine the level of satisfaction of civil servants and students with academic services and quality. Likewise, the institution's policy of motivating the achievement of professors for lecturers is a major concern by providing material assistance to lecturers so that they can write articles and present their writing both at home and abroad. Apart from the policies that have been made for the benefit of the institution, there are things that are urgent and need to make a separate policy to strengthen regulations regarding the duties, functions, code of ethics of ASN and all forms of regulations concerning ASN, namely, policies to deal with behavior that often occurs in the institutional environment which originates from from individual behavior which includes liver disease but has fatal consequences for the institution if it tends to be ignored. Therefore, policy mechanisms and policy implementation strategies are deemed necessary in every organization, especially in higher education institutions, a place to educate the nation's children and the wider community. In order to create a generation of character, smart, healthy, devoted to both parents, useful for the nation and state, educational institutions should adopt praiseworthy behavior starting with ASN as executor and responsible for the realization of academic quality through the implementation of supporting policies for work programs.

In order for policy implementation to run smoothly according to the expectations of the institution, according to researchers, there are three things that become references in policy implementation so that it is more effective, efficient and efficient, namely: 1) First, the preparation of each work program, the placement of civil servants and honorary civil servants, the appointment of ASNs as officials in higher education and the achievement of work program targets should be based on institutional needs, not personal interests, and group interests on behalf of institutional needs and avoid intervention; 2) Second, the placement of ASN in each unit is adjusted to the program implemented and built through the established mechanisms and procedures. Likewise, supervision of routine ASN behavior and performance is carried out through the principles of being transparent, humane, obeying the rules, indiscriminately, dynamic, assertive, responsible and authoritative; 3) Third, everything related to supporting the implementation of policies should be pursued, such as: wider freedom of academic pulpit, career opportunities and promotion for civil servants both inside and outside the institution as long as they do not leave their main duties and responsibilities as ASN in the IAIN environment. Sultan Amai, by always coordinating with the leadership and related parties in order to avoid things that harm the institution. 


\section{Conclusions}

Accuracy in program formulation and policy implementation in tertiary institutions has essentially brought about positive changes in terms of achievement, especially the cultivation and development of the best behavior for the Academic Community and all ASNs in higher education institutions, more specifically at the IAIN Sultan Amai Gorontalo institution. Praiseworthy behavior is shown by ASN which is formed because of the implementation of policies that are made and enforced seriously, procedurally and sustainably can have an impact on institutional development so that it can be accountable not only to the institution itself, the

\section{References}

Aldi, Y., \& Susanti, F. (2019). Pengaruh Stress Kerja Dan Motivasi Kerja Terhadap Prestasi Kerja Karyawan Pada PT. Frisian Flag Indonesia Wilayah Padang.

Ardian, N. (2019). Pengaruh Insentif Berbasis Kinerja, Motivasi Kerja, Dan Kemampuan Kerja Terhadap Prestasi Kerja Pegawai UNPAB. JEpa, 4(2), 119-132.

Indrawan, M. I. (2019). Pengaruh Etika Kerja, Pengalaman Kerja Dan Budaya Kerja Terhadap Prestasi Kerja Pegawai Kecamatan Binjai Selatan. Jurnal Abdi Ilmu, 10(2), 1851-1857.

Rewansyah, Asmawi. 2011. Kepemimpinan dalam Pelayanan Publik. Jakarta: STIA LAN

Sopiah. 2008. Perilaku Organisasional.

Patri Juari widowati Johanes, Analisis Penilain Prestasi Kerja Pegawa Negeri Di Badan Kepegawain dan Pengembangan Sumber Daya Manusia Kabupaten Bulungan Provinsi Kalimantan Utara. Jurnal Ilmu Pemerintahan Suara Khatulistiwa Vol III, NO 01,Juli 2018

Sari Warneri, Maria Ulfah, Analisis Sistem Pengendalian Internal Sekolah Dalam Mengelola Aktiva Tetap.Jurnal Pendidikan dan Pengajaran Katulistiwa, Vol 7 NO 5,2018

Chusminah SM, R.AH Haryanti,Penilain Kinerja Pegawai Pada Bagian Kepegawain dan Umum Direktorat Jendral P2P Kementrian Kesehatan, Junraln Widya Cipta, Vol 3 No 1,2019

Simanjuntak, D. S., Nadapdap, K. M. N., \& Winarto, W. (2017). Pengaruh Persepsi Penilaian Prestasi Kerja terhadap Kepuasan Kerja Karyawan. Jurnal Manajemen, 3(2), 6-13.

Yulia Erha Irblana Efektifitas Penilain Kerja PNS (Pegawai Negeri Sipil)Di Kantor Regional II Badan Kepegawain Negara Surabaya,Jurnal Politico, Vol 3 No 1, 2014

Shinta Bonita Moningka, Efektifitas Kerja Pegawai Negeri Sipil Dalam Pelayanan Publik Kantor Kelurahan Kolongan Kecamatan Tomohon Tengah Kota Tomohon, Jurnal Politico, Vol 3 No 1, 2014

Lyn Smith,Pamela,2009 Mounter Effective Internal Communication,Kogan Page Landon.

Astri Hanjrawati dan Siti Aminah, Evaluasi Implementasi Kebijakan Pemerintah Kota Yogyakarta Mengenai Pendidikan Inklusi, Jurnal Inklusi, Vol 1 No 2,2014

Tanjung, H. (2017). Pengaruh Disiplin Kerja Dan Motivasi Kerja Terhadap Prestasi Kerja Pegawai Pada Dinas Sosial Dan Tenaga Kerja Kota Medan. Jurnal Ilmiah Manajemen Dan Bisnis, 15(1).

Muhammad Aji Ibrahim, Muhammad Jamal,Burhanudin,Faktor-Faktor Yang Mempengaruhi Kinerja Aparatur Sipil Negara (ASN) Dalam Meningkatkan Pelayanan Administrasi Kepada Masyarakat Di Kecamatan Bontang Barat Kota Bontang, e-Jurnal Ilmu Pengetahuan, Vol7 No 2, 2019

Gugun Geusan Akbar, Pengaruh Implementasi Kebijakan Mutasi Pegawai dan Sistem Insentif Penghasilan Pegawai terhadap Motivasi Kerja Pegawai Dalam Meningkatakan Prestasi Kerja dan Disiplin Kerja Pegawai pada Dinas Pendidikan Kabupaten Garut, Jurnal Pembangunan dan Kebijakan Publik, Vol 02 No 2,2010

Ulfah Irani Z, Murniati AR,Khairuddin, Implementasi Manajemen Strategik Dalam Upaya Peningkatan Mutu Pendidikan Pada SMAN 10 Fajar Harapan, Jurnal Administrasi Pendidikan, Vol4 No 2, 2014

Yosy Arisandy, Penilain Kinerja (PERFOMANCE APPRAISAL)Pegawai Negeri Sipil Dengan Menggunakan Kombinasi Methode KEY Performance Indicatordan 360 Degree Feedback, Jurnal AlIlmi, Vol 2 No 1, April 2017

James Haryando Simantupang,Dg Pablik, Sitti Nurchasanah, Peranan Disiplin Kerja Pegawai Terhadap Efektifitas Layanan Masyarakat Di Distrik Sorong Manoi Kota Sorong, Jurnal Faksi Ilmu Sosial dan Ilmu Politik, Vol 2 No 2, 2017

Lubis, A. Y. O., \& Susanti, F. (2019). Pengaruh Gaya Kepemimpinan Dan Kompensasi Terhadap Prestasi Kerja Karyawan (Studi pada PT Japfa Comfeed Indonesia (JCI) Tbk Devisi Fam 1.

Nining Yuningsih, Penerapan Manajemen Kinerja Pegawai Di Instansi Pemerintah, Jurnal Pengembangan Wirasuwasta, Vol 19 No 2, 2017

Nurrofi, A. (2012). Pengaruh Disiplin Kerja Dan Pengalaman Kerja Terhadap Prestasi Kerja Karyawan Pada Departemen Produksi Pt. Leo Agung Raya Semarang. Jurnal Ilmu Manajemen dan Akuntansi Terapan (JIMAT), 3(1). 
Harefa, D. (2020). Pengaruh Antara Motivasi Kerja Guru IPA dan Displin Dengan Prestasi Kerja. Aksara: Jurnal Ilmu Pendidikan Nonformal, 6(3), 225-240.

Yunita Laponte, Moh Tofan Samudin, Fery, Implementasi Kebijakan Disiplin Aparatur Sipil Negara Pada Sekretariat Dewan Perwakilan Rakyat Daerah Provinsi Sulawesi Tengah,Jurnal Kolaboratif Sains, Vol 1No 1, 2019

Abdul Hafid, Implementasi Kebijakan Tentang Disiplin Pegawai Negeri Sipil Pada Dinas Pendapatan, Pengolaaan Keuangan dan Aset Daerah Kota Palu, Jurnal Katalogis, Vol 4 No 9, 2016 